\title{
Perceived Importance of Core Competencies among Extension Professionals in Nepal
}

\author{
Ramjee P Ghimire ${ }^{a,{ }^{*}}$ Murari Suvedi $^{b}$, Michael Kaplowitz $^{b}$, and Robert B. Richardson ${ }^{b}$ \\ ${ }^{a}$ Department of Animal Science, Michigan State University, East Lansing, MI 48824, USA \\ ${ }^{b}$ Department of Community Sustainability, Michigan State University, East Lansing, MI 48824, USA
}

\section{MANUSCRIPT INFO \\ Article history: \\ Received 9 Sep 2020 \\ Received in revised form 14 Apr 2021 \\ Accepted 2 May 2021}

\section{Keywords:}

Agricultural extension services

Extension professionals

Core competencies

\begin{abstract}
A B S T R A C T
Agricultural systems are evolving globally. Farmers and agri-entrepreneurs are demanding trustworthy and efficient extension and advisory services that they can rely on to improve their farming systems and associated enterprises. In this context, extension professionals are expected to be versatile and be competent in their services. Competency refers to having required knowledge, skills and abilities in both process skills and technical subject matters to effectively deliver assigned services. Competency needs are context specific and dynamic. Thus, it is imperative to periodically examine what competencies extension professionals possess and how they value them. This cross-sectional study sought to examine the perceived importance of key competencies among agricultural extension professionals in Nepal. Extension professionals in Nepal's public agricultural and livestock development offices and agriculture-based non-governmental organizations comprised the study population. Survey data were collected from August to September 2015 through self-, group-administered, and web-based questionnaire. The respondents rated eight core competencies as important or very important. Their perceptions of the importance of these core competencies significantly differed across their current positions, level of education, age, and experience in extension services but not across their educational institutions, employers, and gender. There is a need to develop extension education curricula integrating these core competencies and providing education and training on these core competencies to extension professionals.
\end{abstract}

(C) 2021 NAPA. All rights reserved.

\section{Citation:}

Ghimire, R. P., Suvedi, M., Kaplowitz, M., \& Richardson, R. (2021). Perceived importance of core competencies among extension professionals in Nepal. Global Journal of Agricultural and Allied Sciences, 3(1), 8-15.

\section{Introduction}

Globally, the agricultural system is evolving and experiencing new opportunities and challenges. Social, financial, and environmental subsystems that the agricultural system is built on are changing. New pests and diseases are emerging, so also are the technologies to address them. International trade of agricultural commodities and exchange of associated technologies and services are also increasing. While new stakeholders continue to join various agricultural value chains, some of the existing stakeholders recalibrate their association and/or leave the value chain. Thus, functions, interactions, and relationships between and within agricultural systems and the value chains are dynamic. There exists an apparent demand for agricultural extension services that could embrace these changes and support growers to improve their farm production and accrue higher returns. To effectively serve the stakeholders in the changing contexts, extension professionals must be knowledgeable of their subject matters, be skillful to examine their clientele's contexts, and be proactive to adapt and act as demanded.

\footnotetext{
*Corresponding author. E-mail address: ramghi@gmail.com
}

According to Christoplos (2010), "extension includes delivering technical knowledge, and facilitating, brokering and coaching of different actors to improve their access to services and dealing with changes." Extension professionals are the change agents. They work with and for many different groups of stakeholders and garner their support to bring positive changes. They should be able to motivate beneficiaries to adopt new technologies. Extension professionals should be competent, social, flexible, and responsive to the stakeholder needs.

Explaining the term "new extension" as similar to competent extension, Davis and Suleiman (2014) emphasized that extension professionals are required to perform new roles such as linking farmers with credit institutions, input suppliers and market operators, and foster gender integration. For this they need to be competent with social, analytical, and professional skills (Gabathuler, Bachmann, \& Klay, 2011). Swanson (2008) conjectured that most extension professionals have been trained in traditional education system focusing on technical subjects and they may not have the required knowledge of extension process skills.

Extension professionals work in complex and diverse environments, serving stakeholders with varied backgrounds, values, and interests. They 
are expected to serve as the knowledge brokers and must be willing to colearn with stakeholders. Because extension professionals must adapt to the prevailing environment of the stakeholders for greater success, strong interpersonal skills would be indispensable. Ability to formulate and use effective extension approaches appropriate to the political, cultural, institutional, and environmental contexts of stakeholders is another key attribute of extension professionals (Landini, 2016). Facilitating collaboration, coordination, and innovation among stakeholders and becoming a conduit for agricultural development are considered concomitant attributes of extension professionals.

The importance of accountability and demand for appropriate and transparent evaluation and oversight of extension programs cannot be overstated. Therefore, an extension professional must possess the critical attributes that are necessary for the success of the program and credibility of the institution. Some literature on job descriptions of extension professionals in Asia and Africa exist (Davis \& Sulaiman, 2014; Suvedi, Ghimire \& Channa, 2018; Umar et al., 2017) but little is known about their competencies to perform those roles. For instance, agriculture is the mainstay in Nepal with $70 \%$ of the country's population engaged in agricultural enterprises but the agricultural productivity in Nepal is the lowest in the region (GON, 2015). Coverages of improved crop and horticultural varieties and livestock breeds are limited. Because extension workers serve as the bridge between farmers and researchers and help disseminate improved agricultural technologies, assessment of their competencies in delivering extension services and training programs for improved farm productivity is a necessary first step in agricultural transformation in developing countries, including Nepal. Emphasizing this point Belay and Abebaw (2004) noted that the effectiveness of agricultural extension work highly depends on the availability of extension professionals who are qualified, motivated, committed, and responsive to the ever changing social, economic, and political environment.

Little is known about extension core competencies in Nepal. Kunwar (1989) examined perceptions of field extension workers, agricultural officers, and administrators on the importance of services of field extension workers in Nepal's agricultural development. The findings indicated significantly lower performance (3.3) of the extension workers than perceived importance (4.3). Three decades have passed since this study was conducted and the socio-political, economic, farming contexts and roles expected from extension professionals have changed. Nepal is striving to transition from a linear and top-down model of extension to a demanddriven model. Pressure to re-define extension professionals' roles in the changing contexts is enormous. Thus, a study to help design agricultural extension education policy and training programs and prepare extension human resources that can serve in the changing context is a necessity.

\section{Goal and Objectives of the Study}

The overarching goal of this study was to identify the core extension competencies required for extension professionals in Nepal. Specific objectives were to (a) determine the level of importance of extension core competencies as perceived by extension professionals, and (b) examine variation in the perceptions by respondents' demographic characteristics.

\section{Conceptual Framework}

This study was modelled in the competence theory posited by Mulder (2017). Extension professionals' working environment and contexts are changing over time and their roles are also changing too. Extension professionals serve as the bridge between researchers and farmers. Extension professionals constantly interact with their clientele, peers, managers, and other stakeholders. They know the process skills they require to effectively perform their work. They can also gauge the importance of those skills. Okwoche et al. (2011) argued that extension professionals' perceptions are influenced by their perceived role expectations and by their organizational and social environments. Mulder (2017) opined that extension professional's perceptions of process skills vary by their contexts such as the country, region, agricultural commodity, and the socioeconomic environment.

The study used eight core competencies namely, program planning, program implementation, communication skills, use of education and information technology, program evaluation, personal and professional development, diversity, and technical subject matter expertise, representing methodological, individual, social, and technical domains. Recommendations from agricultural education and extension experts in Nepal and a review of the literature were the bases for these eight core competencies (Ghimire, 2016). These are the competencies essential to establish demand-driven extension services (Mulder, 2007; Mulder, Eppink, \& Akkermans, 2011; Rivera \& Alex, 2008).

Competent implies having required knowledge and skills and being able to apply those skills into practice. It also means remaining current with new information and being able to make informed decisions. Abiding by professional ethics and norms and striving to attain professional goals are other attributes of competent professionals. Competency as it relates to extension services refers to understanding diversity (e.g., cultural, social, economic, etc.) and valuing diversity while serving. Competency embraces identification and prioritization of client's needs, participatory program implementation and mapping and tapping of resources for program delivery. Technical abilities to use computers, the Internet, social media, and smart tools in communications are equally critical for extension professionals to succeed. They should be able to evaluate programs and improve them as needed. Competency also demonstrates greater motivation and commitment to program planning and impactful outcome.

\section{Study Methods}

\subsection{Study Design}

Survey data were collected during August-September 2015 through groupadministered, in-person and web-based surveys. The survey method can be used for examining human behaviors as well as program outcomes and impact (Dillman, Smyth, \& Christian, 2009). Previous studies on extension professionals have successfully used personal surveys and self-assessment approaches to examine perceptions (Karbasioun, Mulder, \& Biemans, 2007; Kunwar, 1989). In-person and group-administered surveys typically have high response rates; therefore, these were chosen for this study. Webbased surveys are easy to administer, cost effective and reliable to collect and retrieve data. Those who could not be surveyed in-person participated in the web-based survey. 


\subsection{Population, Sample and Data Collection}

The study population consisted of 1,058 extension professionals in Nepal, including chiefs, subject matter specialists (SMSs), and technical officers (TOs) in District Agricultural Development Offices (DADOs), District Livestock Services Offices (DLSOs) and agricultural program officers in agriculture-based NGOs (PO-NGOs). The sample came from 46 districts representing all three eco-zones and five development regions in Nepal (Figure 1).

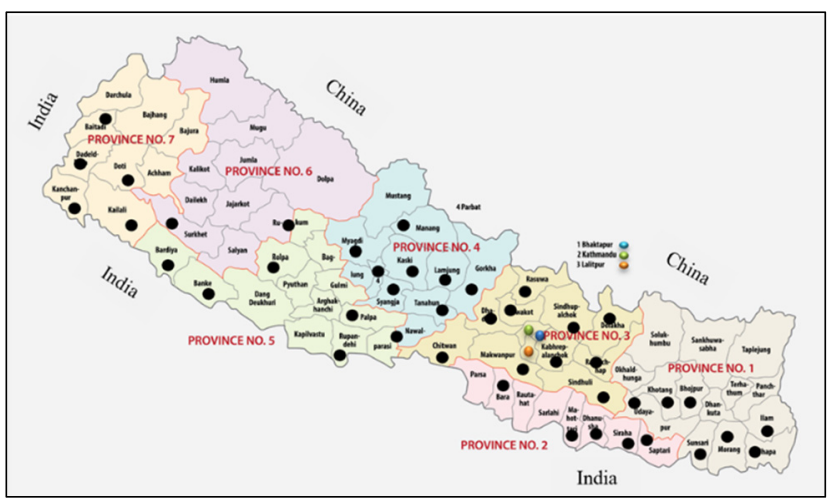

Figure 1. Map of Nepal showing 46 districts representing respondents. (Source for map: https://www.worldatlas.com/maps/nepal)

Most Department of Agriculture (DOA) and Department of Livestock Services (DLS) district staff did not have their individual emails and they used common official emails. Only a few of them had access to the Internet. Therefore, they were met in-person and administered the survey in groups at their respective offices. NGO professionals represented national level NGOs such as Centre for Environmental and Agricultural Policy Research, Extension and Development (CEAPRED), Local Initiatives for Biodiversity, Research and Development (LIBIRD), Rural Reconstruction Nepal (RRN), Resource Identification and Management Society Nepal (RIMS-Nepal), and Heifer International.

\subsection{Survey Instrument}

This study is the second part of a competency assessment study that the first author led. Competencies drawn from literature review and focus group discussions from the first study served as the basis for the survey instrument for this study. Focus groups were held among agricultural extension and education experts in Nepal.

The instrument contained three sections. Section one had eight core competencies each with five to seven statements. Program planning and communication skills had six statements each; program implementation, educational and informational technology, and program evaluation had seven statements each; and personal and professional development, diversity, and technical subject matter expertise had five statements each. Importance of competency was measured in a five-point Likert-type scale: 1 equated as "not important," 2 as "somewhat important," 3 as "average," 4 as "important," and 5 as "very important." Section two contained two questions seeking information on additional competencies required for extension professionals to do their work and appropriate ways to acquire those competencies. Section three was on demographic -- gender, age, extension experience, current position, undergraduate college, and primary work organization.

For objective 1, ratings on the importance of core competencies were variables of interest. For objective 2, ratings of the importance of core competencies were dependent variables. Independent variables were demographic traits: 1) gender; 2) primary organization: Department of Livestock Services (DLS), Department of Agriculture (DOA), Nongovernmental Organization (NGOs); 3 ) experience in extension services in years; 4) current position: DADO or DLSO Chief called as chief, SMS, TO, PO-NGO; 5) age in years; and 6) highest educational level: I. Sc. Ag. or equivalent called as I. Sc., B. Sc. Ag or equivalent called as B. Sc., Postgraduate. The university or college from where undergraduate education was received was another independent variable. They included Tribhuvan University (TU) and Agriculture and Forestry University (AFU), and colleges affiliated to these universities called henceforth as AFU/TU; Purbanchal University (PU) and colleges other than affiliated to TU and AFU in Nepal called as PU; and universities/colleges outside Nepal.

The researcher field-tested the survey questionnaire among 22 extension professionals prior to actual survey. The respondents filled out the survey with the researcher present. They critiqued on the formatting of survey along with the level of difficulty to comprehend meaning of the contents, and they offered suggestions for improvement. The survey was modified integrating their feedback. A panel of experts at Michigan State University and the extension experts in Nepal reviewed the survey instrument and validated the contents.

One side of the in-person survey was in English and the other side in Nepali, the country's national language. Respondents were free to choose either language option. Slightly more than half (52\%) used English version while $48 \%$ chose Nepali version. The large majority were in-person surveys and only $12.6 \%$ were online.

Reliability coefficients calculated post-hoc of eight core competencies ranged from .75 to .90 (Table 1), indicating that the statements were consistent and reliable to measure the perceptions of the respondents (Gliem \& Gliem, 2003).

Table 1. Core competencies and their reliability coefficients.

\begin{tabular}{lll}
\hline Core competency areas & $\begin{array}{l}\text { Number of statements used each core } \\
\text { competency areas }\end{array}$ & $\begin{array}{l}\text { Scale reliability } \\
\text { (Cronbach's alpha) }\end{array}$ \\
\hline Program planning & 6 & 348 \\
Program implementation & 7 & .75 \\
Communication skills & 6 & .81 \\
Educational and informational technology & 7 & 348 \\
Program evaluation & 7 & .79 \\
Personal and professional development & 5 & .86 \\
Diversity & 5 & .90 \\
Technical subject matter expertise & 5 & .83 \\
\hline
\end{tabular}




\section{Data Analysis}

Index scores were calculated and used to examine the overall perceptions of importance and difference between competency scores and variation in perceptions by demographics. Data were analyzed using descriptive statistics (frequency, mean and standard deviation) and inferential statistics (independent sample t-test and repeated measures ANOVA). Repeated measures ANOVA was calculated to examine whether and how there was any significant difference in perceptions for eight core competencies. Differences in perceptions by demographics were calculated using one-way ANOVA and Tukey post-hoc tests. Descriptive statistics of individual competencies are also presented and referred to wherever relevant.

Prior to a detailed analysis, the data were examined for variations in responses (or perceptions) between hard-copy and online, and English and Nepali surveys. As reported in previous studies, it was assumed that those with access to and comfortable with using the Internet and those with comfort in English would rate core competencies highly than those with filling a hard copy survey (Suh, McColde \& Holecek, 2013); contrary were the results. There was no difference in respondents' ratings and the data set from two sources were combined.

\section{Study Findings}

\subsection{Demographics}

Table 2 shows demographics of respondents. The large majority ( $93.1 \%$ of 349) of the respondents were males. Respondents' mean age and experience in extension were 46 and 20.32 years, respectively. About half (46\%) of the respondents were from the DOA, $43.7 \%$ were from the DLS, and $10.3 \%$ from NGOs. On average, $37.2 \%$ held an I. Sc. (12 years of schooling), $23.8 \%$ a B. Sc. degree, and $39 \%$ had a postgraduate degree. Most of the participants $(73.0 \%)$ had completed their undergraduate and/or basic agricultural education at AFU/TU in Nepal; $14.8 \%$ at PU in Nepal; and $12.2 \%$ in colleges outside Nepal. The chiefs made up $19.1 \%$ of the respondents. Approximately one-third (32.2\%) of the respondents were SMSs, $9.9 \%$ were PO-NGOs, and $38.8 \%$ were TOs.

\subsection{Perceptions of Importance}

Respondents rated all eight core competencies to be important or very important to their work (Table 3). Personal and professional development received the highest rating $(\mathrm{M}=4.57, \mathrm{SD}=0.46)$; and receiving the lowest rating $(\mathrm{M}=4.37, \mathrm{SD}=0.49)$ was program evaluation. Of 48 individual competency statements that were the bases of these eight core competency areas, demonstrating positive attitude towards extension work received the highest rating. Fifteen statements have 4.50 or above ratings. All five statements from personal and professional development were rated within this range.
Table 2. Respondents' demographics.

\begin{tabular}{llll}
\hline Demographic characteristics & & $\boldsymbol{N}$ & $\mathbf{\%}$ \\
\hline Gender $(N=349)$ & Female & 24 & 6.9 \\
& Male & 325 & 93.1 \\
& $\leq 35$ years & 72 & 21.1 \\
Age group $(\mathrm{N}=342)$ & $36-50$ years & 120 & 35.1 \\
& $\geq 51$ years & 150 & 43.9 \\
Experience in extension & $\leq 5$ years & 55 & 16.9 \\
$(N=325)$ & 6-10 years & 27 & 8.3 \\
& $11-15$ years & 15 & 4.6 \\
& $16-20$ years & 41 & 12.6 \\
& $\geq 21$ years & 187 & 57.5 \\
Primary organization & DOA & 160 & 46.0 \\
$(N=348)$ & DLS & 152 & 43.7 \\
& NGO & 36 & 10.3 \\
Highest education $(N=344)$ & I. Sc. & 128 & 37.2 \\
& B. Sc. & 82 & 23.8 \\
Undergraduate college/university & Postgraduate & 134 & 39.0 \\
$(N=337)$ & AFU/TU & 246 & 73.0 \\
& PU & 50 & 14.8 \\
& Colleges outside & 41 & 12.2 \\
Current position $(N=345)$ & Nepal & & \\
& Chief & 66 & 19.1 \\
& SMS & 111 & 32.2 \\
& PO-NGO & 34 & 9.9 \\
& TO & 134 & 38.8 \\
\hline
\end{tabular}

Table 3. Overall perception ratings on importance.

\begin{tabular}{lccc}
\hline Core competency areas & $\begin{array}{c}\text { Number of } \\
\text { statements used } \\
\text { to construct the } \\
\text { core }\end{array}$ & N & Mean (SD) \\
& competency & & \\
\hline Program planning & 6 & 348 & $4.44(0.46)$ \\
Program implementation & 7 & 348 & $4.44(0.46)$ \\
Communication skills & 6 & 348 & $4.49(0.44)$ \\
Educational and informational technology & 7 & 348 & $4.41(0.51)$ \\
Program evaluation & 7 & 349 & $4.37(0.49)$ \\
Personal and professional development & 5 & 349 & $4.57(0.46)$ \\
Diversity & 5 & 349 & $4.45(0.48)$ \\
Technical subject matter expertise & 5 & 349 & $4.47(0.50)$ \\
\hline
\end{tabular}

Employing repeated measure ANOVA, the eight core competencies were examined for differences between each other $(\mathrm{N}=345)$ assuming that the perception scores for competencies differed from each other (Table 4). The results of the ANOVA indicated a significant difference between these eight scores, Wilks' Lambda $=.751, F(7)=15.971, p=.000, \eta^{2}=.25$.

Follow up comparisons using Bonferroni test indicated that personal and professional development competency having received the highest rating stood out with all other seven competencies. Program evaluation with the lowest score being different than communication skills, personal and professional development, diversity, and technical subject matter expertise. 
Table 4. ANOVA: single factor: summary

\begin{tabular}{|c|c|c|c|c|}
\hline Core competency areas & Codes & $\mathbf{N}$ & $\begin{array}{l}\text { Mean } \\
\text { (SD) }\end{array}$ & $\begin{array}{l}\text { *Differences } \\
\text { found with }\end{array}$ \\
\hline Program planning & $\mathrm{A}$ & 348 & $4.44(0.46)$ & $\mathrm{F}$ \\
\hline Program implementation & $\mathrm{B}$ & 348 & $4.44(0.46)$ & $\mathrm{F}$ \\
\hline Communication skills & $\mathrm{C}$ & 348 & $4.49(0.44)$ & $D, E, F$ \\
\hline $\begin{array}{l}\text { Educational and } \\
\text { informational technology }\end{array}$ & $\mathrm{D}$ & 348 & $4.41(0.51)$ & $\mathrm{C}, \mathrm{F}$ \\
\hline Program evaluation & $\mathrm{E}$ & 349 & $4.37(0.49)$ & $\mathrm{C}, \mathrm{F}, \mathrm{G}, \mathrm{H}$ \\
\hline $\begin{array}{l}\text { Personal and professional } \\
\text { development }\end{array}$ & $\mathrm{F}$ & 349 & $4.57(0.46)$ & $\mathrm{A}, \mathrm{B}, \mathrm{C}, \mathrm{D}, \mathrm{E}, \mathrm{G}, \mathrm{H}$ \\
\hline Diversity & G & 349 & $4.45(0.48)$ & $E, F$ \\
\hline $\begin{array}{l}\text { Technical subject matter } \\
\text { expertise }\end{array}$ & $\mathrm{H}$ & 349 & $4.47(0.50)$ & $\mathrm{E}, \mathrm{F}$ \\
\hline
\end{tabular}

Note: *The mean difference is significant at the 0.05 level.

\subsection{Differences in Perceptions by Demographics}

Table 5 presents respondents' perceptions of the level of importance of core competencies by demographics.

Primary Organization. One-way ANOVA and Tukey post-hoc tests show significant differences between DOA and DLS respondent groups for their ratings on diversity, and technical subject matter expertise with higher ratings from the former.

Education. One-way ANOVA results show significant differences in ratings on the importance of core competencies for all but one, i.e., personal, and professional development among respondents with their highest educational qualifications. The post-hoc analyses show that respondents with postgraduate degrees perceived program planning to be more valuable than those with intermediate (12 grades) and bachelor's degrees. For program implementation, communication skills, and diversity, postgraduate degree holders rated higher than those with intermediate levels.

Undergraduate, College and/or University, and Age. Respondents who completed their undergraduate education from institutions in Nepal and those who completed from educational institutions outside Nepal held similar views and so also were the perceptions with the three age groups, $\leq$ 35 years, $36-50$ years, and $\geq 51$ years.

Current Position and Experience in Extension. Only difference noticed in perception ratings was on program planning where 6-10-year experience group rated higher than those with less than 5-year experience and with more than 15-year experience groups. Regarding respondents' current position, chiefs rated higher to program planning than their SMSs and Technical Officers (TOs). Further analyses on TOs opinions that differed from other three groups showed (results not shown) TOs ratings to program planning, program implementation and educational and informational technology were significantly lower than the chiefs. Additionally, TOs ratings to educational and informational technology and personal and professional development were significantly lower than SMSs.

Gender. Female respondents' ratings for educational and informational technology, program evaluation, diversity, and technical subject matter expertise were significantly higher than that for males.

Table 5. One-way ANOVA and t-test results showing differences in perceptions of level of importance of core competencies by demographics.

\begin{tabular}{|c|c|c|c|c|c|c|c|}
\hline Core competency & $\begin{array}{l}\text { Primary } \\
\text { organization } \\
\text { F or t-value }\end{array}$ & Education & College & Age & $\begin{array}{l}\text { Extension } \\
\text { experience }\end{array}$ & $\begin{array}{l}\text { Current } \\
\text { position }\end{array}$ & Gender \\
\hline Program planning & 0.463 & $7.316^{* * *(b)}$ & 1.526 & 2.371 & $3.856^{* *}$ & $3.403^{*}$ & 1.169 \\
\hline Program implementation & 0.399 & $3.734 *(\mathrm{c})$ & 1.523 & 0.190 & .721 & 2.180 & 1.407 \\
\hline Communication skills & 0.319 & $4.085^{*}(\mathrm{c})$ & 2.325 & 1.609 & .925 & 0.850 & 1.553 \\
\hline Educational and informational technology & 1.867 & $3.207 *$ & 0.974 & 0.647 & .705 & 2.101 & $2.662 * *$ \\
\hline Personal and professional development & 1.432 & 2.852 & 0.592 & 0.369 & 1.377 & 1.884 & 1.211 \\
\hline Diversity & $3.954 *(a)$ & $4.374 *(c)$ & 2.289 & 2.022 & .944 & 1.438 & $2.473^{*}$ \\
\hline Technical subject matter expertise & $4.819 * *(a)$ & $3.014 *$ & 0.468 & 1.912 & 1.460 & 1.010 & $2.822 * *$ \\
\hline
\end{tabular}

Note. $* P \leq .05, * * p \leq .01, * * * p \leq .001$.

Primary organization: $1=D O A(n=160), 2=D L S(n=152), 3=N G O(n=36) ; a=1>2$

Education: $1=I$. Sc. $(n=127), 2=$ B. Sc. $(n=82), 3=$ Postgraduate $(n=134) ; b=1,2<3, c=1<3$.

College: $1=$ AFU/TU and affiliated colleges $(n=246), 2=P U$ and other non-TU colleges $(n=50), 3=$ Colleges outside Nepal $(n=41)$.

Age (years): $1=\leq 35(n=72), 2=36-50(n=120), 3=\geq 51(n=150)$

Extension experience: $1=\leq 5$ year $(\mathrm{n}=55), 2=6-10$ years $(\mathrm{n}=27), 3=11-15$ years $(\mathrm{n}=15), 4=16-20$ years $(\mathrm{n}=41), 5=\geq 21$ years $(\mathrm{n}=187) ; 2>1,4,5$.

Current position: $1=\operatorname{Chief}(n=66), 2=\operatorname{SMS} / \mathrm{TO}(n=245)$, NGO-PO $(n=34) ; 1>2$.

Gender: female $(n=24)>$ male $(n=324)$ for four core competencies. 


\section{Discussion}

Findings of respondents perceiving all core competencies to be important or very important to their profession indicate that they are aware of extension process skills and value their roles and responsibilities in the extension profession. The findings are consistent with those of Ghimire and Martin (2011) in the U.S.; Okwoche et al. (2011) and Lopokoiyit et al. (2013) in Africa; and Namdar, Rad and Karamidehkordi (2010) and Movahedi and Nagel (2012) in Iran; and Ramjattan, Wayne and Chowdhury (2017) in Trinidad and Tobago. Thus, it would be reasonable to say that Nepalese extension professionals hold similar values or perceptions of core competencies to those of their counterparts across the developing countries. The revelation of higher ratings ( 4.5 or higher) to all statements on personal and professional development counter a general observation that extension professionals are not interested in learning new things and are inattentive to their profession. As is obvious, the higher ratings are indicative of their wish to receive additional in-service training to enrich their skills and improve their performance and be professional.

Though rated positively, the lowest rating for program evaluation indicates that extension professionals in Nepal do not yet think program evaluation should get a precedence. The findings support the fact that evaluation of extension services is limited in Nepal and systematic and unbiased evaluation of extension services is needed (Suvedi \& McNamara, 2012). Furthermore, agricultural education in Nepal is predominantly based on technical curricula. Very little coverage is given to process skills including program evaluation and opportunities for training on this topic during their services (in-service) is also limited (Ghimire, 2016). Lower rating to program evaluation is likely the outcome of a combination of these factors.

The DOA professionals perceiving technical subject matter expertise to be more important to their work than with DLS professionals might be because of DOA respondents holding a strong technocentric worldview believing that technical interventions can solve most farming problems. The higher rating on diversity by DOA respondents resonates with the fact DOA has been providing necessary training on diversity to its extension staff and mobilizing them to serve diverse group clients that include but not limited to small, marginal and women farmers (DOA, 2017).

The higher perceived values to core competencies by those with the postgraduate degrees show that education and training not only contribute to attaining higher technical competency but also to process competencies. This finding contrasts with those of Burke (2002), who found that respondents' educational level had no influence on their ratings of importance of core competencies. Respondents with 12 years of education (least educated group) perceived core competencies to be less important to their work than other respondents with the higher education. This could be due to the lack of opportunities for orientation and thus being less aware of core competencies.

The finding that ratings for program planning are significantly higher for chiefs than SMS/TOs are consistent with Namdar et al. (2010), but it contrasts to Burke (2002), who reported no differences in competency

\footnotetext{
* Corresponding author. E-mail address: ramghi@gmail.com
}

ratings by extension worker's position. Technical Officers work closely with farmers and their being positive and motivated to provide extension services is paramount to educate and better serve farmers. The lowest ratings for planning, program implementation and educational and informational technology by TOs indicate otherwise.

Significantly higher ratings for educational and informational technology, program evaluation, diversity and technical subject matter expertise by female respondents indicate them being more affirmative to, eager to and willing to hone these competencies. These findings support Okwoche et al. (2011) and Place et al. (2007) that women extension workers perceive technologies to be more important than the men did. Consistent with the findings of Quisumbing and Pandolfelli (2010) is that women extension workers are more cognisant of their roles and preferred over their male counterparts. The findings challenge Burke (2002) that extension workers hold similar values about extension core competencies irrespective of their gender.

Age and experience are important predictors for developing a favorable perception towards services (Ramjattan et al., 2017). Akinsorotan and Oladele (2009) and Ramjattan et al. (2017) noted that extension agents develop positive perception of organizational value as they gain more experience. The finding of our study did not corroborate with this as perceptions remained same irrespective of age, and only difference in experience was for higher rating to program planning by a group with 6-10 years' experience in extension services. The findings contradict Burke (2002) but support Brodeur et al. (2011). Brodeur argues that extension workers' perceptions of competencies change with age and experience and suggests a change in training areas as workers gain experience.

\subsection{Study Limitations}

The small size of female and NGO samples is a limitation of this study. However, it should be noted that there are only about $8 \%$ female workers among total agriculture extension workers in Nepal (GFRAS, 2018). Therefore, the current sample size is reflective of the female extension worker population in Nepal. All the measures used in the study relied on self-report and self-assessment. In general, individuals tend to overrate when they do not have to bear any private cost and vice versa. Some degree of such overrating, thus biases, cannot be ruled out in this study as respondents were assured that they did not have to bear any cost, except for their time and input, for participating in the study. Opinion of immediate supervisors and beneficiaries, which were beyond the scope of this study, would have helped triangulate the results. In addition, because it was a cross-sectional study, it could not show the temporal changes in perceptions of the respondents.

\section{Conclusion and Recommendations}

This study sought to examine Nepalese agricultural extension professionals' perceptions of the importance of extension core competencies suggested by experts. The study revealed that respondents are aware that eight core competencies experts suggested are critical for 
successful implementation of extension services, and they should have a good understanding of those competencies to effectively deliver extension and advisory services to their clientele. Respondents hold high regard for extension profession. They are willing to continue to improve their knowledge and skills on extension and are committed to better serve their clientele. Respondents felt that their personal and professional development was of utmost importance in sustaining their effectiveness. This infers that they are looking forward to additional opportunities for professional development and applying personal and professional competency in their services. Program monitoring and evaluation is perceived to be of lesser priority for extension services in Nepal. Pre-service education appears to have a significant bearing on respondents' perceptions, thus their competencies.

A holistic approach to revamp agricultural extension education mobilizing competent instructors to educate students in extension core competencies is urgently needed for extension program effectiveness. Regular refresher and hands-on training on core competencies would be worthwhile to enhance the positivity of the extension professionals toward extension profession. An agricultural extension education policy that ensures pre-service and in-service education focusing on extension core competencies is suggested. There should be a policy to strengthen institutions offering extension education and enable them to provide quality education in both process and technical skills.

\section{References}

Akinsorotan, A. O., \& Oladele, O. I. (2009). Organizational values perceived as evident among extension agents of agricultural development program in Nigeria. Agricultura Tropic ET Subtropica, 42(3), 110-117.

http://www.agriculturaits.czu.cz/pdf_files/vol_42_3_pdf/akinsorotan.pdf

Belay, K., \& Abebaw, D. (2004). Challenges facing agricultural extension agents: A case study from South-Western Ethiopia. African Development Review, 16 (1): 139-168. doi: 10.1111/j.1467-8268.2004. 00087.x.

Brodeur, C. W., Higgins, C., Galindo-Gonzalez, S., Craig, D. D., \& Haile, T. (2011). Designing a competency-based new county extension personnel training program: A novel approach. Journal of Extension, 49(3), n3. http://www.joe.org/joe/2011june/pdf/JOE_v49_3a2.pdf.

Burke, T. (2002). Defining competency and reviewing factors that may impact knowledge, perceived importance and use of competencies in the 4- $H$ professional's job (Doctoral dissertation). Department of Adult and Community Education, North Carolina State University.

Christoplos, I. (2010). Mobilizing the potential of rural and agricultural extension. Rome: Food and Agricultural Organization. http://www.fao.org/docrep/012/i1444e/11444e.pdf.

Davis, K., \& Sulaiman, R. (2014). The new extensionist: Roles and capacities to strengthen extension and advisory services. Journal of International Agricultural and Extension Education 21(3), 6-18. doi:10.5191/jiaee.2014.21301.

Dillman, D. A., Smyth, J. D., \& Christian, L. M. (2009). Internet, mail, and mixed-mode surveys: The tailored design method. $3^{\text {rd }}$ ed. Hoboken, NJ: John Wiley \& Sons.

DOA. (2017). Annual Report. Department of Agriculture, Ministry of Agricultural Development, Nepal.

GFRAS. (2018). Worldwide extension study, Asia, Southern Asia, Nepal. https://www.g-fras.org/en/world-wide-extension-study/92-world-wideextension-study/asia/southern-asia/314-nepal.html.
Ghimire, N. R., \& Martin, R. A. (2011). Needs assessment competencies: Are they important for extension educators? International Journal of Agricultural Management and Development (IJAMAD,) 1(3).

Ghimire, R. P. (2016). Assessment of core competencies of extension professionals in Nepal. Dissertation. Department of Community Sustainability, Michigan State University, East Lansing, MI.

Ghimire, R. P., \& Suvedi, M. (2017). A qualitative study examining core competency needs of agricultural extension professionals in Nepal. Asian Journal of Agricultural Extension, Economics \& Sociology, 18(3), 1-12. ISSN: 2320-7027.

Gliem, J. A., \& Gliem, R. R. (2003). Calculating, interpreting, and reporting Cronbach's alpha reliability coefficient for Likert-type scales. Midwest Research-to-Practice Conference in Adult, Continuing, and Community Education.

https://scholarworks.iupui.edu/bitstream/handle/1805/344/Gliem\%20\%26 $\% 20$ Gliem.pdf?sequence=1\&isAllowed=y.

GON (Government of Nepal). (2015). Agricultural Development Strategy 2015-2035 Part:1. Kathmandu: Government of Nepal (GON).

Karbasioun, M., Mulder, M., \& Biemans, H. (2007) Towards a Job competency profile for agricultural extension instructors: A survey of views of experts. Human Resource Development International, 10(2), 137151.

Kunwar, N. (1989). Roles of field level agricultural extension workers in Nepal as perceived by agricultural extension personnel. Retrospective Theses and Dissertations. 9144. https://lib.dr.iastate.edu/rtd/9144.

Landini, F. (2016). How to be a good rural extensionist? Reflections and contributions of Argentine practitioners. Journal of Rural Studies, 43,193202. http://dx.doi.org/10.1016/j.jrurstud.2015.11.014.

Lopokoiyit, M., Onyango, C., \& Kibett, J.K. (2013). extension management competency needs of agricultural extension agents in Kenya. Mediterranean Journal of Social Sciences 4(6), 11.

Movahedi, R., \& Nagel, U. J. (2012). Identifying required competencies for the agricultural extension and education undergraduates. Journal of Agricultural Science and Technology, 14(4), 727-742.

Mulder, M. (2007). Competence - The essence and use of the concept in ICVT. European Journal of Vocational Training 40, 5-21.

Mulder, M. (2017). Competence theory and research: A synthesis. In: Mulder M. (Eds.) Competence-based Vocational and Professional Education. Technical and Vocational Education and Training: Issues, Concerns and Prospects, Vol 23. Springer.

Mulder, M., Eppink, H., \& Akkermans, L. (2011). Competence-based education as an innovation in East-Africa. In ECER conference, Berlin.

Namdar, R., Rad, G. P., \& Karamidehkordi, E. (2010). Professional competencies needed by agricultural and extension program evaluation staff and managers of Iranian Ministry of Agriculture. Journal of International Agricultural Extension Education 17(2), 21-31.

Okwoche, E. P., Ejembi, E. P., \& Obinne, C.P.O. (2011). Professional competencies perceived to be important and needed by female and male agricultural extension agents: A study from Nigeria. Journal of Agricultural Sciences 2(2), 121-126.

Place, F., Adato, M., Hebinck, P., \& Omosa, M. (2007). Impacts of agroforestry-based soil fertility replenishment practices on the poor in western Kenya. In M. Adato, \& R. Meinzen-Dick (Eds.). Agricultural research, livelihoods, and poverty: Studies of economic and social impacts in six countries. Washington, D.C.: International Food Policy Research Institute.

Quisumbing, A. R., \& Pandolfelli, L. (2010). Promising approaches to address the needs of poor female farmers: Resources, constraints, and interventions. World Development 38(4), 581-592.

Ramjattan, J., Wayne, G., \& Chowdhury, A. (2017). value of modern extension methods in improving image and quality of extension: Perception of extension agents in Trinidad and Tobago. Journal of Agricultural Extension and Rural Development, 9(8), 155-162. 
Rivera, W. M., \& Alex, G. E. (2008). Human resource development for modernizing the agricultural workforce. Human Resource Development Review 7 (4): 374-386. doi:10.1177/1534484308324633.

Serim, H., Demirbag, O., \& Yozgat, U. (2014). The effects of employees' perceptions of competency models on employability outcomes and organizational citizenship behavior and the moderating role of social exchange in this effect. Procedia-Social and Behavioural Sciences, 150, 1101-1110. doi: 10.1016/j.sbspro.2014.09.125.

Suh, J., McCole, D., \& Holecek, D. (2013). A Comparison of Mail and Internet Survey Procedures.

https://scholarworks.umass.edu/cgi/viewcontent.cgi?article=1046\&context =nerr.

Suvedi, M., Ghimire, R. P., \& Channa, T. (2018). Examination of core competencies of agricultural development professionals in Cambodia.
Evaluation and Program Planning, 67, 89-96. https://doi.org/10.1016/j.evalprogplan.2017.12.003.

Suvedi, M., \& McNamara, P. (2012). Strengthening the pluralistic agricultural extension system in Nepal. MSU/MEAS/USAID.

Swanson, B. E. (2008). Global Review of Good Agricultural Extension and Advisory Service Practices. Rome, Italy: Food and Agricultural Organizations (FAO).

Umar, S., Man, N., Nawi, N. M., Latif, I. A., \& Samah, B. A. (2017). Core competency requirements among extension workers in peninsular Malaysia: Use of Borich's needs assessment model. Evaluation and Program Planning, 62, 9-14. 